in musical improvisation the musical relationship between therapist and patient may be seen as revealing aspects of the patient, which include his or her capacity for establishing, sustaining and developing a relationship with another person. Alternatively, the improvisation may be seen as an adjunct or trigger to a verbal relationship between therapist and patient, in which feelings elicited during the musical activity may be discussed. Improvisation may also be used with patients who have physical disorders, where it provides an opportunity for them to hear their movements in sounds which are given musical meaning by the therapist. The therapist can provide the possibility for extending these movements, by improvising music which invites and motivates the patient to play (and move) in different ways.

Although the studies cited by the authors provide an important theoretical foundation for the use of music in therapy, the profession has evolved well beyond the patient as passive listener, or even musicas-recreation. This is thanks to the pioneering work of figures such as Juliette Alvin, Mary Priestley, Paul Nordoff and Clive Robbins. Kenneth Bruscia's book Improvisational Models of Music Therapy (1987, Charles C. Thomas, Springfield, III) provides a commanding overview of music therapy.

MERCEDES PAVLICEVIC Music Therapist and Research Associate

University of Edinburgh

Department of Psychology

Edinburgh EH8 9JZ

\section{Responsibility of the Child and Adolescent Psychiatrist in Multidisciplinary Teams \\ DEAR Sirs}

At a recent meeting of the Wessex Child Psychiatrists the advice contained in the Psychiatric Bulletin, (September 1989, 13, 521) was discussed.

The paragraph containing the sentence "such clinical responsibility must be terminated only by agreement with the child's general practitioner" gave rise to much concern. Our group felt that the need for termination of clinical responsibility should be determined by the consultant. In addition we agreed with many of the points raised in the letter of the Leicester Child Psychiatrists group (Psychiatric Bulletin, March 1990, 14, 175).

We thought that it would have been helpful if the advice had been circulated in draft form by the College for comments by the members before a definitive statement was issued.

W. A. SAunders Chairman

Wessex Child Psychiatrists
DEAR SIRS

This note is a comment on the two letters that have appeared in the Psychiatric Bulletin on the responsibility of child and adolescent psychiatrists in multidisciplinary teams. Issues of medical protection are only one of the many areas where the enlightened practice of child psychiatry (and increasingly other branches of psychiatry and community paediatrics), fit uneasily into the mould developed for the main body of medical practice.

Following detailed discussion with the medical protection agencies guidelines for practice were outlined, and were discussed with the Child Psychiatry Section Executive Committee and other relevant College committees before approval by Council in June 1989.

The letters raised the matter of consultation. Members of the Section must be aware that there are many similar issues being dealt with by their elected Executive Committee. While it is not College policy to circulate draft documents to the total membership, the current officers have instituted a newsletter for the membership. This is intended to inform members of the ongoing issues being considered and to invite comment. It is hoped that members will make use of this opportunity to join in the debate.

A. R. NiCOL

University of Leicester

Department of Psychiatry

Westcotes House

Westcotes Drive

Leicester LE3 OQU

\section{Qualifications for appointments to substantive consultant posts}

DeAr SirS

In his letter (Psychiatric Bulletin, January 1990, 14, 43) Dr Cottrell looked forward to the day when members of Advisory Appointments Committees would finally obtain "... relief from the grim ritual of making no short lists or appointments from a field largely comprised of locum consultants with no senior registrar training of any kind".

Training at the senior registrar (SR) level is important, and I fully support this programme as part of the process of maintaining good standards of clinical practice in the emergent corps of consultants. Nevertheless, as we all know, there are many 'intangible' factors that go into the making of a consultant. Is SR training the only way to acquire these qualities?

One of the 'intangible' factors that distinguish consultants from non-consultant medical staff is experience. The locum consultants to whom Dr Cottrell refers have done, and continue to do, all the things consultants do. Some have been involved in teaching 